\title{
Prevalence of Enuresis among Secondary School Adolescents in Enugu, Nigeria.
}

\author{
${ }^{1,2}$ Nwokocha ARC (MBBS,FMCPaed), ${ }^{2}$ Onukwuli VO (MBBS, MPH, \\ FMCPaed), ${ }^{2}$ Ujunwa AF (MBBS,MPH,FMCPaed), ${ }^{1,2}$ Okafor HU \\ (MBBS,FMCPaed,FWACP), ${ }^{3}$ Onyemelukwe NF (BSc,MSc,PhD). \\ ${ }^{I}$ Department of Paediatrics, College of Medicine, University of Nigeria, Enugu Campus. \\ ${ }^{2}$ Department of Paediatrics, University of Nigeria Teaching Hospital, Ituku-Ozalla, Enugu. \\ ${ }^{3}$ Department of Microbiology, College of Medicine, University of Nigeria, Enugu Campus.
}

\begin{abstract}
Enuresis is an important problem among secondary school adolescents. It results in psychosocial disturbances. Knowledge ofits prevalence, types and associated factors willguide proper management.The objective of the study was to determine the prevalence, types and associated factors of enuresis among secondary school adolescents in Enugu. This cross sectional study was carried out in six secondary schools in Enugu town. Self-administered pre-tested questionnaire was used to collect information. Data was analyzed using descriptive statistics and chi square tests. 626 adolescents consisting 302 males and 324 females were studied. Overall prevalence of nocturnal enuresis was $15.82 \%$. Of this, $3.7 \%$ also had diurnal enuresis. $33.3 \%$ had primary enuresis, while $66.7 \%$ had secondary enuresis. Gender had no significanteffect on this prevalence. The age range 10-13 years had the highest prevalence of 17.6\%. Emotional disturbance and family history of enuresis were significant predictors of enuresis.
\end{abstract}

Key Words: Adolescents, Enugu, Enuresis, Prevalence.

\section{Introduction}

Enuresis is a disorder characterized by repeated voiding of urine into the clothes or in bed of persons with a chronological age or developmental level of at least five years that is not due exclusively to the direct physiological effect of a substance or a general medical condition.[1] It may be classified into subtypes according to its occurrence during night- time sleep (nocturnal), during waking hours (diurnal) or both and may be described as primary among individuals who have never achieved urinary continence or as secondary among persons developing symptoms after a period of established urinary continence.[1] A child who has experienced a minimum 6-month period of continence before the onset of the bedwetting is considered to have secondary enuresis.[2] There are variations in the prevalence rates of enuresis according to the population and classification type under review.[1]It may be more common among younger children with resolution of symptoms in the vast majority of cases by puberty. In America, Prevalence rates for enuresis are estimated to be approximately $5-10 \%$ among children aged $5-15$ years,[1] while in Europe $9-19 \%$ of children aged $5-10$ years old had enuresis. [3,4] In Africa, a prevalence rate of $11.5 \%$ was reported in Egypt [5] while in Nigeria, higher rates of $22.2 \%, 23.2 \%$ and $21.3 \%$ were documented in Zaria,[6] Port Harcourt [7] and Edo [8] respectively in children aged 5-16years. In a study done strictly on adolescents in Port Harcourt, Anochie [9] reported a prevalence rate of $25.3 \%$. Nocturnal enuresis is three times more common than daytime wetting.[2,10,11] and secondary causes account for less than $25 \% .[12,13]$ Bedwetting was more frequent in boys than in girls. $[12,13]$ Although it is sometimes considered a trivial complaint, enuresis can be a significant problem for the affected child and his family. Data from several studies show that enuresis can have far-reaching consequences on the individual, including effects on self-perception, with reduced self-esteem, $[14,15]$ interpersonal behaviour, sexual activity and quality of life.[16] Persistent bedwetting may compromise the relationship between parents and children, with parents feeling anxious, guilty and eventually experiencing loss of confidence in their parental skills, and children losing self-confidence, having difficulties in making friends and under-achieving at school.[17] Enuresis can be dramatically distressing as age increases; adult enuretics report being reluctant to go on holidays or staying away overnight (33\%), that bedwetting is a terrible experience (40\%), that it has a major influence in their life (32\%), and complicates their relationships (23\%).[18]Evidence of the great strain that enuresis may represent and the recent observation that enuresis may persist into adulthood, [16,18] prompted us to assess the population of adolescent enuretics. Epidemiological surveys in adults report an overall incidence of nocturnal enuresis of $0.5-2.3 \%$, with no significant differences in the different age groups.[17,18] Thus enuresis may affect at least $1-2 \%$ of adolescents. Reports on enuretic adolescents have so far appeared only sporadically; hence the aim of the present study was to evaluate the characteristics and associated factors of adolescents with enuresis in Enugu. 


\section{Subjects and methods}

From April to July 2011, 652 adolescents between the ages of 10-21 years, attending different secondary schools in Enugu were recruited for the study. The secondary schools in Enugu Urban were categorized into Private and Public Schools and also into males, females and mixed schools. These schools were further classified based on their location in either the low densely populated or high density populated parts of the town. The students were selected by multi -stage stratified random sampling to represent all the categories noted above. One hundred and ten students were selected from each of the schools. (27 or 28 students each from JS1\&2 and SS1\&2, those of them in JS3 and SS3 were involved in their certificate exams at the time of the study). One in every four student was picked according to their class sitting arrangement.

Participation was voluntary and all those who did not give informed consent were excluded. Approval for the study was given by the Research and Ethics committee of the University of Nigeria Teaching Hospital, Enugu. Permission was also obtained from the Enugu State Ministry of Education as well as the School's authorities. Data was collected using structured, pretested, self-administered questionnaire. Information on socio-demographic characteristics as well as enuresis and its associated factors were obtained. Clean-catch urine samples were collected and analyzed for possible bacterial growth. Statistical analyses were carried out using the Statistical Package for Social Sciences (SPSS), version 15.0 for windows. Chi-square test was used to test for significant variables while correlation and logistic linear regression analyses were used to determine the predictive factors for enuresis; $\mathrm{p}$-values of $<0.05$ were considered to be statistically significant.

\section{Results}

A total of 660 questionnaires were given out and 652 were returned, giving an overall response rate of $98.8 \%$. However, 26 questionnaires were discarded due to incomplete data. 626 were eventually analyzed. Of these, 302(48.2\%) were males and 324(51.8\%) were females, giving a male: female ratio of 1:1.1. The mean age of these students was $15.03 \pm 1.97$ years. The age and sex distribution of the participants are as shown in Table1.

\subsection{Prevalence and types of enuresis.}

The overall prevalence of nocturnal enuresis was $15.8 \%(\mathrm{n}=99)$, that of nocturnal-diurnal enuresis was $3.7 \%(\mathrm{n}=23)$. None of the students had only diurnal enuresis. This prevalence was higher in the males $16.2 \%$ $(n=49)$ than in the females $15.4 \%(n=50)$, though this was not statistically significant $\left(x^{2}=0.24, d f=1, p=\right.$ $0.35)$. Primary enuresis was seen in $33.3 \%(n=33)$ of the students with enuresis while secondary enuresis was seen in $66.7 \%(n=66)$. The adolescents aged $10-13$ years had the highest prevalence of enuresis $(17.6 \%)$ while those aged 18-21years had the lowest (13.8\%) as shown in Table 2.

\subsection{Factors associated with enuresis}

Among the factors considered to affect enuresis were family history of enuresis, socio-economic status, emotional disturbance and positive bacterial growth in urine specimen. Using Correlation analysis, enuresis was found to have a weak positive association with family history of enuresis $(\mathrm{r}=0.10)$, socio-economic status $(\mathrm{r}=$ $0.03)$ and emotional disturbance $(r=0.12)$. However, a weak negative association was observed with positive bacterial growth in urine $(\mathrm{r}=-0.05)$. On further analysis using binary logistic regression analysis, family history of enuresis $(\mathrm{O} . \mathrm{R}=1.74, \mathrm{p}=0.0 .011)$ and emotional disturbance $(\mathrm{O} . \mathrm{R}=1.87, \mathrm{p}=0.005)$ were found to be good predictors of enuresis while social class did not predict enuresis $(\mathrm{O} . \mathrm{R}=1.98, \mathrm{p}=0.23)$ (Table 3$)$.

\section{Discussion}

The high response rate (98.8\%) was probably due to the distribution method of the questionnaires which was by way of the schools' head teachers. Enuresis was found to be common among younger secondary school adolescentsand its frequency decreased with increasing age. The overall prevalence of enuresis of $15.8 \%$ reported in this study is lower than that obtained in other studies involving adolescents in Nigeria. Anochie [9] in Port Harcourt documented a prevalence of $25.3 \%$ in students aged 10-21years while Iduoriyekemwen[8] in Edo State documented $21.3 \%$ in children aged 5-16 years. A prevalence of $22.2 \%$ was obtained in children 5-14 years in Zaria.[6] The higher prevalence values obtained in the last two studies could possibly be due to the lower ages of the children studied since enuresis has been shown to be commoner in the younger age group. However, the prevalence of $25.3 \%$ in the Port Harcourt study [9] which used the same age range as this study may be from the fact that they included students who had been bedwetting after the age of 5 years who may have stopped at the time of the study while this study considered those bedwetting during the period of the study. Again, enuresis is said to be worse in cold weather.[19] This may have also contributed to the higher prevalence rate obtained in Port Harcourt which has a cool weather compared to Enugu where this study was carried out. The prevalence rate of enuresis reported in Nigeria is higher than $1.96 \%, 1.7 \%$, and $0.7 \%$ reported in adolescents in China [20]Canada [21] and Italy [22] respectively. Generally, a wide variation in the prevalence of enuresis has been documented in different places. The different definitions of enuresis used, as 
well as Socio-cultural and economic differences in these regions may be responsible. Again enuresis in childhood is often considered a trivial problem such that Medical attention is hardly sought. This is more so in developing countries including Nigeria, thus most children continue to have enuresis till adolescence or even adulthood resulting in high prevalence rates in these periods. Strict day time enuresis was not documented in this study. This may confirm its rarity as was noted by Iduoriyekemwen[8] in Edo state and Bakwin in London.[23] Gender did not have a significanteffect on the prevalence rate of enuresis. This was also reported in other studies.[5,24] Althoughmale predominance was found in studies performed within[8,9] and outside Nigeria,[20,25]the generalprinciple about gender in a Malaysian study[26]showed that, enuresis was more common in boys inthe early years but equals with the females in the latter years. This study was on adolescents who are in the transition period of development. Secondary enuresis is the commoner type of enuresis found in this study. Although this contradicts the findings in some studies, $[2,8]$ it is not surprising, as this is the period when children leave home for school, and some changes known to be associated with anxiety could precipitate enuresis even in those who may have stopped bed-wetting. However, an analysis of the presence of other possible causes of secondary enuresis will highlight its higher prevalence as found in this study. Emotional disturbance was shown to be a significant predictor of enuresis and tends to support the higher prevalence of secondary enuresis noted in this study. Family history of enuresis was also noted to predict enuresis in this study. This has similarly been documented in other studies. $[2,8,20]$ and lays credence to the fact that enuresis has genetic basis. Moreover, an autosomal dominant inheritance linked to chromosomes 8,12,13,22 has been described.[27,28] Although family history of enuresis is commoner with primary enuresis, which has a lower prevalence in this stud, it is possible that some students that were primary enuretics with genetic predisposition may become secondary enuretics when exposed to other factors. Socioeconomic status was not a significant predictor of enuresis in this study. This was also noted by Singh et al in India [29] and contradicts the findings of Chiozza et al [13] and Ali Gunes et al [24] where socioeconomic status influenced enuresis. Positive bacterial growth in urine showed a negative association with enuresis in this study. This is not surprising because, although urinary tract infection has been reported in $5-10 \%$ of children with enuresis usually diurnal type, $[9,30,31]$ the students with positive growth in their urine had asymptomatic bacteriuria and did not have features of urinary infection. Again this study did not document any case of diurnal enuresis which is the commoner type associated with urinary tract infection.

\section{Tables}

Table 1 - Age and sex distribution of the students

\begin{tabular}{|lccc|}
\hline Age range & Males $(\%)$ & Females $(\%)$ & Total $(\%)$ \\
\hline $10-13$ years & $47(15.6)$ & $101(31.2)$ & $148(23.7)$ \\
\hline $14-17$ years & $211(69.8)$ & $209(64.5)$ & $420(67.0)$ \\
\hline $18-21$ years & $44(14.6)$ & $14(4.3)$ & $58(9.3)$ \\
\hline Total & $302(100.0)$ & $324(100.0)$ & $626(100.0)$ \\
\hline
\end{tabular}

Table 2 - Prevalence of enuresis in the different age groups.

\begin{tabular}{|lcc|}
\hline Age ranges & No. & Enuretic $(\%)$ \\
\hline $10-13$ years & 148 & $26(17.6)$ \\
\hline $14-17$ years & 418 & $65(15.6)$ \\
\hline $18-21$ years & 58 & $8(13.8)$ \\
\hline Total & 626 & $99(15.8)$ \\
\hline
\end{tabular}

Table 3 - Binary logistic regression of the predictors of enuresis

$\beta \quad$ S.E Wald p-value odds ratio 95\% C.I (odds)

*statistically significant.

\begin{tabular}{|lccccccc|}
\hline Family history & 0.55 & 0.22 & 6.40 & $0.011^{*}$ & 1.74 & 1.13 & 2.68 \\
\hline Social class & 0.18 & 0.51 & 1.44 & 0.23 & 1.98 & 0.89 & 1.61 \\
\hline Emotional upset & 0.63 & 0.22 & 8.05 & $0.005^{*}$ & 1.87 & 1.21 & 2.88 \\
\hline
\end{tabular}

\section{Conclusion}

Enuresis is common among the studied adolescents. Family history and emotional disturbance may influence it. Awareness of its prevalence as well as prompt and adequate medical attention is recommended. 
The following are hereby acknowledged:

\section{Acknowledgements}

MrChukwumaIredu for assisting in the statistical analysis of the study.

The Principals, teachers and students of the following schools in Enugu, where the study was conducted. Queens high school, May blossom secondary school, Uwani boys secondary school, Good shephard seminary, Lady Ibiam secondary school and Government secondary school.

\section{References}

[1]. Samuel T Gontkovsky. Prevalence of enuresis in a community sample of children and adolescents referred for outpatient clinical psychological evaluation: Psychiatric comorbidities and association with intellectual functioning.Journal of child and adolescent mental health23 (1).2011, 53-58.

[2]. AttiaZein AT, Amr AS. Nocturnal enuresis at a Primary Health Care Setting: Analysis of 117 cases. Bahrain Medical Bulletin, 33 ( 2)June 2011

[3]. Nappo S, Del Gado R, Chiozza ML, et al. Nocturnal enuresis in the adolescent: a neglected problem. BJU International, 90(9), 2002, 912-917.

[4]. Butler RJ. Annotation: night wetting in children: psychological aspects. J Child Psychol Psychiatry, 39, 1998, 453 - 63

[5]. Mohammad A, Mohsen D. Nocturnal Enuresis among School Children in Menofia Governorate, Egypt: a hidden problem. Journal of American Science, 8(1), 2012

[6]. Mbibu NH, Ameh EA, Shehu AU, et al. The prevalence of enuresis among primary school children in Zaria, Nigeria.Nigerian Journal of Surgical Research 7(1), 2005,182-186.

[7]. Paul NI, Alikor EAD, Anochie I. Prevalence of enuresis among primary school children in Port Harcourt. Nigerian Journal of Paediatrics 39(1), 2012,18-21.

[8]. Iduoriyekemwen NJ, Ibadin MO, Abiodun PO. Survey of Childhood Enuresis in the Ehor Community, the EDO State, Nigeria.Saudi J Kidney Dis Transpl17 ,2006, 177-82

[9]. Anochie IC, Ikpeme E. Nocturnal enuresis among secondary school students in Port Harcourt, Nigeria Medical Journal , 1(1),2006 ,12-16.

[10]. Stein MA, Mendelsohn J, Obermeyer WH, et al. Sleep and behavior problems in school aged children. Pediatrics 107(4), 2001 , E60.

[11]. Bower WF, Moore KH, Shepherd RB, et al. The Epidemiology of Childhood Enuresis in Australia.Br J Urol 78(4), $1996,602-6$.

[12]. Robson WL, Leung AK. Secondary Nocturnal Enuresis.ClinPediatr (Phila), 39(7), 2000, 379-85.

[13]. Chiozza ML, Bernardinelli L, Caione P, et al. An Italian epidemiological Multicentre Study of Nocturnal Enuresis. Br J Urol 81 ( 3), 1998,86-9.

[14]. Moffat MEK, Kato C, Pless IB. Improvements in self-concept after treatment of nocturnal enuresis: randomized controlled trial. J Ped 110, 1987,647- 52

[15]. Hagglof B, Andren O, Bergstrom E, et al. Self-esteem in children with nocturnal enuresis and urinary incontinence: improvement of self-esteem after treatment. EurUrol 33 (3), 1998, 16 - 9

[16]. Hirasing RA, Van Leerdam FJM, Bolk-Bennink L, et al. Enuresis nocturna in adults. Scan J UrolNephrol 31,1997, 533 - 6

[17]. Morison MJ. Parents' and young people's attitude towards bedwetting and their influence on behaviour including readiness to engage and persist with treatment. Br J Urol 81 (3), 1998,56- 66

[18]. Yeung OK, Sihoe JDY, Sit FKY, et al. Characteristics of primary nocturnal enuresis in adults: an epidemiological study. BJU Int 87 (1), 2001,52

[19]. Robert H. Euresis. The British Medical Journal 2, 1937,206-208.

[20]. Jian GW, Qing WW, Yue C, et al. An epidemiological study of primary nocturnal enuresis in Chinese children and adolescents.European Urology 49(6), 2006, 939-1152.

[21]. Kanbur N, Pinhas L, Lorenzo A, et al. Nocturnal enuresis in adolescents with anorexia nervosa: Prevalence, potential causes, and pathophysiology. Int. J. Eat. Disord, 44, 2011, 349-355.

[22]. Del Gado R, Del Gaizo D, Chiozza ML. L'enuresinell'adolescente. Minerva Pediatr,52, 2000,559 - 62

[23]. Bakwin H. The genetics of enuresis. In: Kolvin I, Mackeith RC and Meadow SC (eds) Bladder Control and Enuresis(Heineman Publishers London 1993) 73-7.

[24]. Ali G, Gulsen G, Yasemin A, et al. The epidemiology and factors associated with nocturnal enuresis among boarding and daytime school children in southeast of Turkey: a cross sectional study. BMC Public Health9,2009,35

[25]. Ouedraogo A, Kere M, Ouedraogo T, et al. (1997). Epidemiology of enuresis in children and adolescents aged 5-16 years in Ouagadougou. Arch Pediat4, 1997, 947-50.

[26]. Kanaheswari Y. Epidemiology of childhood nocturnal enuresis in Malaysia. J Paediatr Child Health 39(2), 2003, 118-2.

[27]. Caldwell PH, Edgar D, Hodson E, et al. Bedwetting and toileting problems in children. Med J Aust, 182 (4), 2005, 190-5.

[28]. Schmitt BD. Nocturnal enuresis. Pediatr Rev 18, 1997,183-91.

[29]. Singh H, Kaur L, Kataria SP. Enuresis: analysis of 100 cases. India Pediatr. 28(4) , 1991, 375-80.

[30]. Nigel B, Gary S, Robert W (eds) Incontinence. In: Essential Urology.( $2^{\text {nd }}$ edition. London:Churchill Livingstone1994)277-288

[31]. Jones B, Gerrard JW, Shokeir MK, et al. Recurrent Urinary infection in girls; relation to enuresis. CanMed.Assoc J 106, 1972, 127130 